\title{
Carbon Sequestration Potential in Oil Palm-Cocoa Cropping System Grown in Andhra Pradesh under Irrigated Conditions
}

\author{
H.P. Bhagya* and K. Suresh \\ ICAR-Indian Institute of Oil palm Research Pedavegi, West Godavari Dist. \\ Andhra Pradesh, India \\ *Corresponding author
}

\section{A B S T R A C T}

\section{Keywords}

Carbon stock, Sequestration, Oil palm, Cocoa and biomass

Article Info

Accepted: 04 April 2018 Available Online: 10 May 2018
A study was carried out in an adult Oil Palm (Elaeis guineensis) plantation intercropped with cocoa (Theobroma cocoa) grown in sandy loam soil to study the effect of cropping system on above ground carbon sequestration. Non-destructive method for calculating standing biomass of oil palm and cocoa were used. Based on this biomass data carbon stock and $\mathrm{CO}_{2}$ sequestered from the system were estimated. The standing biomass of Oil Palm, Cocoa and Oil Palm with Cocoa were 95.33 t.ha ${ }^{-1}$, 59.96 t.ha $^{-1}$ and 155.29 t.ha $^{-1}$, respectively, while the carbon stock of oil palm, cocoa and oil palm with cocoa were in order of $47.66 \mathrm{t}^{-h a^{-1}}, 29.98$ t.ha $^{-1}$ and 77.64 t.ha $^{-1}$ and the $\mathrm{CO}_{2}$ sequestration of oil palm, cocoa and oil palm + cocoa intercropped system were 174.93 t.ha ${ }^{-1}, 110.02$ t.ha $^{-1}$ and 284.95 t.ha $^{-1}$ respectively. Based on these results, Cocoa could be an ideal intercrop in adult oil palm plantation for enhanced $\mathrm{CO}_{2}$ sequestration in the system.

\section{Introduction}

Oil palm (Elaeis guineensis Jacq.) is perennial vegetable oil yielding crop and it is having a potential of yielding 4-6 t.ha ${ }^{-1}$ oil. In oil palm plantation, interspace will be more and it could be effectively used for cropping system for sustainability in oil palm.

Cocoa is the best suited crop and almost all the oil palm growing farmers in Andhra Pradesh are adopting this system in an area of 5000 ha. Forests, cultivated lands and grass lands are source of carbon sequestration apart from soil. Capturing of atmospheric carbon and storing it in the terrestrial biosphere is one of the options, which have been proposed as a mitigation option for greenhouse gas reduction (GHG) reduction. In united Nations Framework Convention on Climate change (UNFCCC) clean development mechanism, agroforestry (Annon, 2017; Albrecht and Kandji, 2003; Montagnini and Nair, 2004), forestation and reforestation (Shrestha et al., 2005) are designated for carbon trade.

Thus agroforestry as a land use system is receiving wider recognition not only in terms of agriculture sustainability but also in the perspective of climate change. Efforts are on to include some other perennial systems like plantation crops into this mechanism. Once 
these systems are approved for carbon trade, one can expect large demand for plantation crop systems in terms of information on carbon sequestration potential and sustainable productivity. Oil palm cocoa mixed crop not only gives a sustainable production, but also serve as a good system for biomass production and carbon accumulation. Agro forestry system of cocoa with shade trees have been reported to be good examples of biomass production in Costa Rica (Beer et al., 1990).

Oil palm is grown either as monocrop or intercropped with other plantation crops like cocoa, lemon, etc., whereas, cocoa is grown only as an intercrop of either coconut or Arecanut or oil palm. These crops provide shade for under-storied cocoa, forming a considerable amount of land use system that provides sustenance to oil palm growers. Demand for the cocoa is ever increasing in India and also at global level, making this plantation crop more remunerative. On the other hand, oil palm is being consumed as edible oil and also bakery product preparation in India. However, the income levels of farmers are highly fluctuating owing to market dynamics. These suggest the importance of stable income from oil palm - cocoa plantation system. Exploiting carbon sequestration potential of this system is important not only for augmented income, but also for mitigating GHG emissions in the perspective of climate change.

With this view, this study on carbon sequestration was taken up in oil palm cocoa cropping system. In this paper, use of models to calculate biomass, the net primary productivity in terms of biomass production and carbon stock and $\mathrm{CO}_{2}$ sequestration in the system are discussed. The objective of this paper is to analyze carbon sequestration and storage in oil palm-cocoa agroforestry system and discuss the role they can play in reducing the concentration of $\mathrm{CO}_{2}$ in the atmosphere.

\section{Materials and Methods}

A field study was carried out in an adult oil palm (Elaeis guineensis Jacq.) - cocoa (Theobroma cocoa) cropping system grown in sandy loam soil of west Godavari district, Andhra Pradesh and planted in $9 \mathrm{~m}$ triangular spacing with 143 palms/hectare and cocoa were planted in between palm rows at a spacing of $7.65 \times 7.65 \mathrm{~m}$ which could accommodate 170 plants/ha. Ten replications were used in the study. Standard agronomic package of practices were followed. Biometric observations like height $(\mathrm{m})$ of palm up to crown from the base were taken by marked aluminium pole and canopy area $\left(\mathrm{m}^{2}\right)$ of cocoa was measured in two directions of canopy spread (East-West and North -South) and average of these two directions were considering for biomass calculation of cocoa, stem girth $(\mathrm{cm})$ of cocoa at $50 \mathrm{~cm}$ height from the base, stem height $(\mathrm{m})$ of cocoa upto base of crown from the base were taken. Nondestructive methods in the form of regression model were followed for calculating above ground biomass of oil palm and cocoa.

The standing biomass of cocoa is calculated as per Balakrishna and Nair (1989).

Total dry weight $=-8.41+0.47$ $\mathrm{CA}+0.28 \mathrm{SG}+2.69 \mathrm{SH}$

Where, CA-Canopy area $\left(\mathrm{m}^{2}\right)$, SG- Stem girth (cm), SH- Stem height (m) upto base of crown

The standing biomass of oil palm is calculated as per regression model (Khalid et al., 1999)

$\mathrm{W}=725+197 \mathrm{H}$

Where, W- Total fresh weight $(\mathrm{kg}), \mathrm{H}$ - Height $(\mathrm{m})$, Fresh to dry weight $=\mathrm{Wx} 0.27$

Based on biomass obtained from the nondestructive methods, carbon stocks and $\mathrm{CO}_{2}$ 
sequestered from the system was estimated. The biomass to carbon stock conversion factor was 0.5 as per IPCC, 2003. The $\mathrm{CO}_{2}$ sequestration was calculated by using a factor of 3.67 as per Balakrishna, 2011. Statistical analyses were performed using Statistical Analysis System 9.3 computer software (SAS Institute Inc., 13).

\section{Results and Discussion}

Oil palm- cocoa is known to be an ideal cropping system as cocoa effectively utilizes the space and add lots of biomass to the system. As shown in table 1, the standing biomass of cocoa was 59.96 t/ha with carbon stock of $29.98 \mathrm{t} / \mathrm{ha}$ and it sequestered 110.02 $\mathrm{t} / \mathrm{ha} \mathrm{CO}_{2}$ from the atmosphere. In Arecanut plantation estimated standing biomass of cocoa has been about $3 \mathrm{t} / \mathrm{ha}$ in third year of field plantation to about 27 t/ha by the time plantation attained 15 years age after field planting (Balasimha, 2011). Cocoa with oil palm plantation possesses more carbon stock as compared to cocoa with arecanut plantation due to the variation in planting density. In standing biomass of oil palm was $95.33 \mathrm{t} / \mathrm{ha}$ with $47.66 \mathrm{t} / \mathrm{ha}$ carbon stock and $\mathrm{CO}_{2}$ sequestration of $174.93 \mathrm{t} / \mathrm{ha}$. Similar results in oil palm above ground biomass ranging from $25 \mathrm{t} \mathrm{C} / \mathrm{ha}$ to over $50 \mathrm{tC} / \mathrm{ha}$ has been recorded by Germer and Sauereborn (2008); Khalid et al., 1999 found $85.3 \mathrm{t}$ biomass $(42.65 \mathrm{Ct} / \mathrm{ha})$ with 136 palms per hectare. These results were closely related with Corley et al., (1971) and Suresh and Kiran Kumar (2011). As shown in Figure 1 oil palm cocoa cropping system recorded highest biomass 155.29 t/ha with 77.64 t/ha C stock and 284.95 t/ha Csequestration. Studies by Sohrabi et al., 2016 reported more carbon storage in above ground than below ground other plantation crops. The higher carbon storage in above ground components in Elder pine (Pinus eldarica) is $50.62 \mathrm{Mg} / \mathrm{hm}^{2}$ followed by Arizona cypress $\left(25.72 \mathrm{Mg} / \mathrm{hm}^{2}\right)$. Bhagya et al., 2017 reported that coconut based fruit cropping system (50 year coconut with 7 year old fruit crops) with above ground carbon storage viz. Coconut + Jamun (60.93 t/ha), coconut + mango (56.45 $\mathrm{t} / \mathrm{ha})$, coconut + Garcinia (53.02 t/ha) and coconut monocropping (51.14 t/ha). Oil palm with cocoa sequestered more carbon stock compared to that of coconut and fruit cropping systems which might be due to contribution of more carbon stock by cocoa in the oil palm cocoa cropping system.

Fig.1 Oil palm based cocoa cropping system $\mathrm{CO}_{2}$ sequestration t/ha

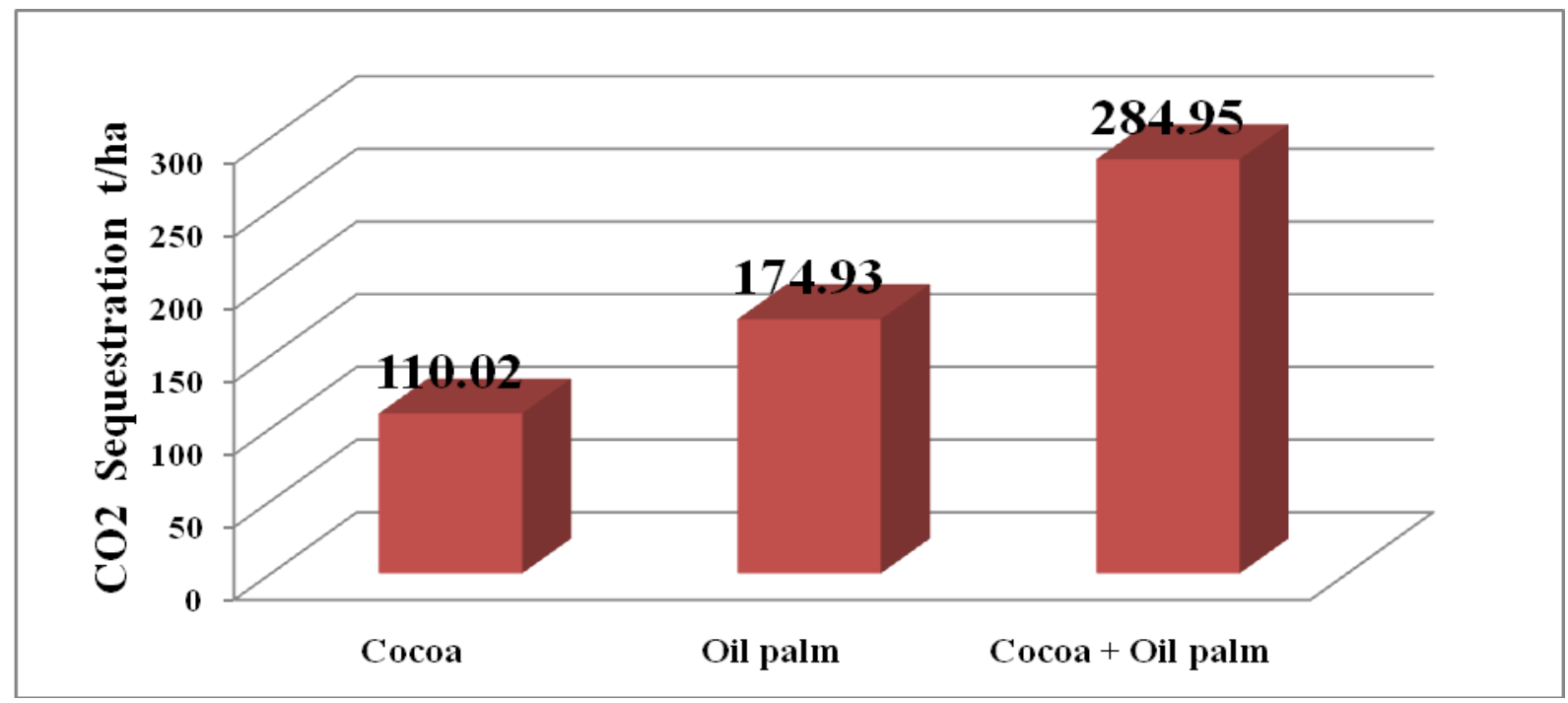


Table.1 Estimated biomass, $\mathrm{C}$ stock and $\mathrm{CO}_{2}$ sequestered (t/ha) in oil palm, cocoa and oil palm + cocoa cropping system

\begin{tabular}{|l|l|l|l|}
\multicolumn{1}{c|}{ Treatments } & \multicolumn{1}{|c|}{ Biomass (t/ha) } & Carbon stock (t/ha) & $\mathrm{CO}_{2}$ sequestered (t/ha) \\
\hline Cocoa & 59.96 & 29.98 & 110.02 \\
\hline Oil palm & 95.33 & 47.66 & 174.93 \\
\hline Cocoa + Oil palm & 155.29 & 77.64 & 284.95 \\
\hline CV $(\%)$ & 5.55 & 5.55 & 5.55 \\
\hline SE (d) & 2.57 & 1.29 & 4.71 \\
\hline LSD at 5 \% & 5.4 & 2.7 & 9.9 \\
\hline
\end{tabular}

To conclude, cocoa could be an ideal intercrop in oil palm- cocoa based cropping system as it could sequester more carbon than sole oil palm crop.

\section{References}

Albrecht, A. and Kandji, S., 2003. Carbon sequestration in tropical agroforestry system. Agric Ecosys Environ. 99: 1527.

Annonymous, 2017. Indian bags key post in UNFCCC. The Hindu (May 16, 2017). www.thehindu.com/news/national/India n-bags -key-post-in-fccc/article1846912 7.ece

Balasimha and Nair, 1989, Biomass estimation of Cocoa plant by regression analysis. J. Plantation Crops, 17: 57-59.

Balasimha, D., 2011, Biomass productivity, carbon stock and carbon sequestration of cocoa in relation to planting density and canopy regimes. Journal of Plantation Crops, 39(1): 174-176.

Beer, J., Bonnemann, W., Chavez, H.W., Fassbender, H.W., Imbach, A.C and Martel, I. 1990. Modelling agroforestry systems cocoa (Theobroma cacao) with laurel 9Cordia alliodora or poro (Erythrina poeppigiana) in Costa Rica. $\mathrm{V}$. productivity indices, organic material models and sustainability over ten years. Agrofor syst. 12: 229-249.

Bhagya H.P., Maheswarappa H.P., Surekha, Bhat Ravi, 2017. Carbon sequestration potential in coconut-based cropping systems. Indian Journal of Horticulture, 74(1): $1-5$

Corley, R. H. V., Hardon, J. J and Tan, G. Y., 1971, Analysis of growth of the oil palm (Elaeis guineensis Jacq.). I. Estimation of growth parameters and application in breeding. Euphytica, 20: 307-315.

Gibbs, H.K., Brown, S., Niles, J.O, 2007. Monitoring and estimating tropical forest carbon stocks: making REDD a reality. Environ. Res. Lett. 2: 045023.

IPCC (Intergovernmental panel on Climate Change), 2003, In: Penman J. et al., (eds.) Good practice guidance for land use, land use change and forestry (GPGLULUCF), IPCC-IGES, Japan.

Khalid, H., Zin, Z.Z and Anderson, J.M., 1999, Quantification of Oil palm biomass and nutrient value in a mature plantation. I. Above ground Biomass. $J$. Oil palm Research, 11(1): 23-32.

Montagini, F. and Nair, P.K.R. 2004. Carbon sequestration; an underexploited environmental benefit of agroforestry system. Agrofor Syst. 61; 281-295.

SAS Institute. 1995. SAS/STAT guide for personal computer version 6. SAS Institute, Cary, NC.

Shrestha, R.M., Sharma, S., Timilsina, G.R. and Kumar, S. 2005. Baselines for afforestation and reforestation (A and $\mathrm{R})$ projects. In: Baseline methodologies for clean development mechanism 
project. (Myung-Kyoon Lee Ed.) UNEP, Roskilde, Denmark. Pp. 120143.

Sohrabi, H., Bakhtiarvand-Bakhtiari, S., Ahmadi, K., 2016. Above and below ground biomass and cabon stocks of different tree plantations in central Iran. J. Arid Land. 8(1): 138-145.

Suresh, K.and Kiran Kumar, M., 2011, Carbon Sequestration Potential of Oil palm under Irrigated and Rainfed Condition. Indian J. Dry land Agric. Res. And Dev., 26 (2): 55-57.

\section{How to cite this article:}

Bhagya, H.P. and Suresh, K. 2018. Carbon Sequestration Potential in Oil Palm-Cocoa Cropping System Grown in Andhra Pradesh under Irrigated Conditions. Int.J.Curr.Microbiol.App.Sci. 7(05): 358-362. doi: https://doi.org/10.20546/ijcmas.2018.705.046 